\title{
SOUTH CAROLINA
}

\section{GROUND-WATER QUALITY}

\author{
By Gary K. Speiran, U.S. Geological Survey \\ and
}

Richard W. Oldham, Donald A. Duncan, and Raymond L. Know South Carolina Department of Health and Environmental Control

U.S. Geological Survey Open-File Report 87-0751 


\section{DEPARTMENT OF THE INTERIOR \\ DONALD PAUL HODEL, Secretary}

\section{U.S. GEOLOGICAL SURVEY}

Dallas L. Peck, Director

For additional information:

Chief Hydrologist

U.S. Geological Survey

407 National Center

Reston, VA 22092
For sale by:

U.S. Geological Survey

Books and Open-File Reports Section

Federal Center

Box 25425

Denver, Colorado 80225

Use of trade names in this report is for descriptive purposes only and does not constitute endorsement by the U.S. Geological Survey 


\section{FOREWORD}

This report contains summary information on ground-water quality in one of the 50 States, Puerto Rico, the Virgin Islands, or the Trust Territories of the Pacific Islands, Saipan, Guam, and American Samoa. The material is extracted from the manuscript of the 1986 National Water Summary, and with the exception of the illustrations, which will be reproduced in multi-color in the 1986 National Water Summary, the format and content of this report is identical to the State ground-water-quality descriptions to be published in the 1986 National Water Summary. Release of this information before formal publication in the 1986 National Water Summary permits the earliest access by the public. 
Ground-Water Quality $\ldots \ldots \ldots \ldots \ldots \ldots \ldots \ldots \ldots \ldots \ldots \ldots \ldots \ldots \ldots \ldots \ldots \ldots$

Water-Quality in Principal Aquifers $\ldots \ldots \ldots \ldots \ldots \ldots \ldots \ldots \ldots \ldots \ldots \ldots \ldots \ldots$

Background Water Quality $\ldots \ldots \ldots \ldots \ldots \ldots \ldots \ldots \ldots \ldots \ldots \ldots \ldots \ldots \ldots$

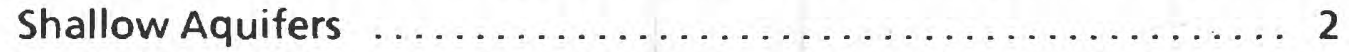

Floridan Aquifer System and Tertiary Sand Aquifer .......... 2

Black Creek and Middendorf Aquifers .................. 2

Piedmont and Blue Ridge Aquifers $\ldots \ldots \ldots \ldots \ldots \ldots \ldots \ldots .2$

Effects of Land Use on Water Quality ..................... 2

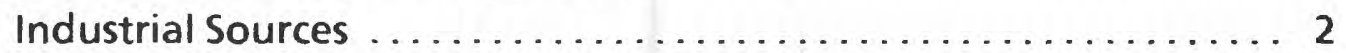

County and Municipal Sources $\ldots \ldots \ldots \ldots \ldots \ldots \ldots \ldots \ldots \ldots$

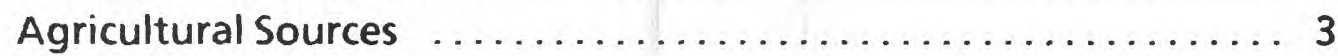

Domestic Sources .............................. 3

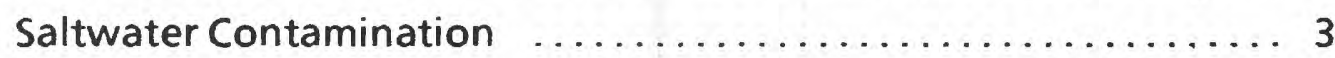

Potential for Water-Quality Changes $\ldots \ldots \ldots \ldots \ldots \ldots \ldots \ldots \ldots$

Ground-Water-Quality Management $\ldots \ldots \ldots \ldots \ldots \ldots \ldots \ldots \ldots \ldots$

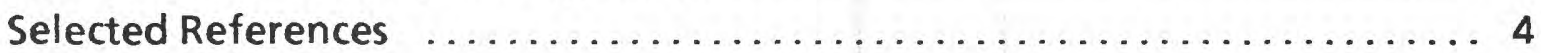

Illustrations

Figure 1.--Selected geographic features and 1985 population distribution in South Carolina.

Figure 2.--Principal aquifers and related water-quality data in

South Carolina.

Figure 3.--Selected waste sites and ground-water quality information in South Carolina.

Figure 4.--Water quality along flow paths from the recharge area toward the coast in the Floridan aquifer system and the Tertiary sand aquifer, the Black Creek aquifer, and the Middendork aquifer in South Carolina. 


\section{South Carolina Ground-Water Quality}

Ground water is the source of supply for 42 percent of the population of South Carolina (fig. 1). Twenty-two percent of the public water supplies and almost 100 percent of the domestic water supplies rely on ground-water sources (Lonon and others, 1983). Withdrawal for these supplies accounts for 68 percent of the total ground-water withdrawals in the State. Almost all ground water used for public supply is withdrawn from Coastal Plain aquifers because they have greater water storing and transmitting characteristics than the Piedmont and Blue Ridge aquifers (U.S. Geological Survey, 1985, p. 382).

Ground-water quality throughout much of the State is good for most uses. Water-quality impairment or limitations on the use of ground water for public supply are caused primarily by natural geochemical processes rather than by widespread degradation of water quality by human activities (fig. 3 ). Ground-water contamination induced by human activities generally is localized and associated with chemical spills, waste disposal, or saltwater intrusion.

South Carolina lies within three physiographic provinces: Coastal Plain, Piedmont, and Blue Ridge (fig. 2). The principal aquifers used for water supply consist of unconsolidated to semiconsolidated sedimentary rocks in the Coastal Plain province and fractured igneous and metamorphic rocks and the overlying saprolite in the Piedmont and Blue Ridge provinces (U.S. Geological Survey, 1985, p. 379). The Coastal Plain is divided, based on the groundwater hydrology into the upper Coastal Plain toward the Fall Line (inland margin of Coastal Plain sediments) and the lower Coastal Plain toward the Atlantic Ocean (fig. 2).

The Coastal Plain aquifers consist of either limestone or clastic sediments. The Floridan aquifer system (fig. 2) is the only major limestone aquifer. The clastic aquifers include the shallow aquifers, the Tertiary sand aquifer, the Black Creek aquifer, and the Middendorf aquifer. Calcareous material in many of the clastic aquifers increases in abundance toward the coast. The Tertiary sand aquifer is equivalent in geologic age to the limestone units that compose the Floridan aquifer system. The water-table aquifers consist of the shallow aquifers in the lower Coastal Plain; the upper parts of the Tertiary sand, Black Creek, and Middendorf aquifers where they crop out in the upper Coastal Plain; and the saprolite and parts of the fractured rocks of the Piedmont and Blue Ridge aquifers.

The background quality of ground water meets most national drinking-water standards (U.S. Environmental Protection Agency, 1986a,b). Naturally impaired water quality (fig. 3) has concentrations that exceed the drinking-water standards of one or more of the following variables in much of the State: $\mathrm{pH}$, dissolved solids, chloride, iron, manganese, and fluoride. Although the standards establish no primary concentration limits for sodium, concentrations of several hundred milligrams per liter are present in water from aquifers in part of the lower Coastal Plain. Concentrations of these constituents result from natural geochemical and hydrologic processes.

Human-induced ground-water contamination has been identified at 28 of 33 sites monitored under the Federal Resource Conservation and Recovery Act (RCRA) of 1976; at 17 of the 19 sites listed or proposed for evaluation under the Comprehensive Environmental Response, Compensation, and Liability Act (CERCLA) of 1980; and at numerous other sites (fig. 3). In addition, the U.S. Department of Defense (DOD) has identified 17 sites at 4 facilities where contamination has warranted remedial action.

Human-induced contamination generally extends over limited areas. Leaking underground tanks storing gasoline or other liquids have major potential for contamination in the State, but investigations of this potential have begun only recently. Although the poten- tial for saltwater intrusion exists along the coast where potentiometric gradients have been reversed due to pumping, intrusion has been documented only locally. Widespread contamination from regional land-use practices such as agriculture and urbanization has not been documented.

Ground-water quality has been evaluated in several programs conducted by the U.S. Geological Survey and its cooperators and by State agencies. Numerous wells throughout the State have been sampled only once but others are sampled periodically. Publicsupply wells are sampled every 3 years. Monitoring wells near sites of potential contamination are sampled quarterly or biannually. Along the coast, samples are collected semiannually to monitor saltwater intrusion.

\section{WATER QUALITY IN PRINCIPAL AQUIFERS}

The quality of water differs considerably within individual Coastal Plain aquifers, reflecting the effects of flow patterns and differences in the mineralogy of the sediments (figs. $2 C$ and 4). Concentrations of most constituents are small near recharge areas close to the Fall Line (fig. 2A2) where sediments consist primarily of silicate minerals that react slowly with ground water. Concentrations increase downgradient toward the coast (fig. 4), where water has been in contact with the sediments for a longer time and where sediments contain more calcite and marine clays that react more rapidly with the ground water. In the Piedmont and Blue Ridge aquifers, concentrations of several constituents are related to geologic belts, whereas concentrations of other constituents are not (Patterson and Padgett, 1984).

\section{BACKGROUND WATER QUALITY}

A graphic summary of selected water-quality variables compiled from the U.S. Geological Survey's National Water Data Storage and Retrieval System (WATSTORE) is presented in figure $2 C$. The summary is based on dissolved-solids, hardness (as calcium carbonate), nitrate (as nitrogen), sodium, and fluoride analyses of water samples collected from 1946 to 1985 from the principal aquifers in South Carolina. Percentiles of these variables are compared to national standards that specify the maximum concentration or level of a contaminant in drinking-water supply as established by the U.S. Environmental Protection Agency (1986 a,b). The primary maximum contaminant level standards are health related and are legally enforceable. The secondary maximum contaminant level standards apply to esthetic qualities and are recommended guidelines. The primary drinking-water standards include a maximum concentration of $10 \mathrm{mg} / \mathrm{L}$ (milligrams per liter) nitrate (as nitrogen) and $4 \mathrm{mg} / \mathrm{L}$ fluoride. The secondary drinking-water standards include maximum concentrations of $500 \mathrm{mg} / \mathrm{L}$ dissolved solids and $2 \mathrm{mg} / \mathrm{L}$ fluoride.

As a result of naturally impaired water quality, several primary and secondary drinking-water standards are exceeded in one or more aquifers (fig. $2 \mathrm{C}$ ). The only primary or health-related standard that is exceeded in major areas is the $4.0 \mathrm{mg} / \mathrm{L}$ limit for fluoride; all other standards that are exceeded are secondary or esthetic, including the secondary standard of $2.0 \mathrm{mg} / \mathrm{L}$ for fluoride. Additional secondary drinking-water standards established by the U.S. Environmental Protection Agency (1986b) are 6.5-8.5 units of $\mathrm{pH}, 300 \mu \mathrm{g} / \mathrm{L}$ (micrograms per liter) iron, $50 \mu \mathrm{g} / \mathrm{L}$ manganese, and $250 \mathrm{mg} / \mathrm{L}$ chloride. The secondary standards for $\mathrm{pH}$, iron, and manganese, although exceeded in raw water, can be attained by treatment using relatively inexpensive processes. The only major area in which standards are exceeded in one or more aquifers and 
cannot be attained by relatively inexpensive treatment is along the coast where dissolved solids, chloride, and fluoride exceed the standards. Even though the $\mathrm{pH}$ of water supplies can be adjusted after withdrawal, low $\mathrm{pH}$ before adjustment corrodes well screens and casings, decreasing the usable life of wells. Well casings and screens made of polyvinyl chloride (PVC) are used in many domestic and small public-supply wells to alleviate the effects of low $\mathrm{pH}$ on wells. Stainless-steel screens (usually used in large-capacity wells) decrease, but do not eliminate, the effects.

\section{Shallow Aquifers}

Water quality in shallow aquifers is locally more variable than in other aquifers and is more likely to be affected by land use than the deeper, confined aquifers. Water in the shallow aquifers near the coast may contain concentrations of chloride that exceed the $250-\mathrm{mg} / \mathrm{L}$ secondary drinking-water standard as a result of the mixing of freshwater with saltwater, but the problem is not extensive. Although water from the shallow aquifers exceeds the standards for nitrate and fluoride in some areas, these areas appear to be limited in areal extent. The drinking-water standard most commonly exceeded in water from the shallow aquifers is for dissolved iron, $300 \mu \mathrm{g} / \mathrm{L}$.

\section{Floridan Aquifer System and Tertiary Sand Aquifer}

The Floridan aquifer system and the Tertiary sand aquifer are discussed collectively to illustrate their hydraulic connection and the water-quality changes caused by a facies change from limestone to sand. (figs. $2 B$ and 4). Concentrations of dissolved solids are less than $50 \mathrm{mg} / \mathrm{L}$ (fig. 4) and $\mathrm{pH}$ is less than 6.0 near recharge areas, but both increase sharply downgradient with the increase of calcareous material in the aquifer. Dissolved-solids concentrations increase to several hundred milligrams per liter, and the water quality is dominated by calcium and bicarbonate ions. Hardness of the ground water changes from soft to very hard (fig. $2 C$ ). Concentrations of iron exceed the $300-\mu \mathrm{g} / \mathrm{L}$ secondary drinking-water standard in some upgradient areas.

Mixing of freshwater with saltwater results in a dominance of chloride and sodium ions in parts of both aquifers along the coast. Natural concentrations of chloride exceed the $250-\mathrm{mg} / \mathrm{L}$ secondary drinking-water standard in many of these areas.

\section{Black Creek and Middendorf Aquifers}

The water quality of the Black Creek and Middendorf aquifers is similar. Water quality within these units changes significantly from the upper Coastal Plain near recharge areas to the lower Coastal Plain near the coast (fig. 4).

In the upper Coastal Plain, concentrations of dissolved solids are less than $50 \mathrm{mg} / \mathrm{L}, \mathrm{pH}$ generally range from 4.5 to 6.0 , and bicarbonate is $10 \mathrm{mg} / \mathrm{L}$ or less. Thus, $\mathrm{pH}$ is less than the 6.5 minimum secondary drinking-water standard throughout most of the upper Coastal Plain. Iron concentrations exceed the $300-\mu \mathrm{g} / \mathrm{L}$ drinking-water standard in a band in the northern part of the upper Coastal Plain where concentrations are as much as several thousand micrograms per liter. The major ions that dominate the water quality are variable in this part of the upper Coastal Plain, and silica comprises as much as one-half of the dissolved solids (Aucott and Speiran, 1986, p. 42). Water-quality characteristics in the Black Creek and Middendorf aquifers in the upper Coastal Plain reflect the quality of recharge water and the slow reaction rates between the ground water and the silicate minerals that compose the aquifers.

In the lower Coastal Plain ground water is predominantly a sodium bicarbonate type that results from dissolution of carbonate material and subsequent calcium-for-sodium exchange. The $\mathrm{pH}$ ranges from 8.0 to 9.2 , exceeding the 8.5 maximum drinking-water standard in much of the area. Concentrations of dissolved solids and fluoride exceed the secondary drinking-water standards (500 $\mathrm{mg} / \mathrm{L}$ and $2.0 \mathrm{mg} / \mathrm{L}$, respectively) in a band along the entire coast (fig. 3B). Concentrations of fluoride also exceed the $4.0-\mathrm{mg} / \mathrm{L}$ primary drinking-water standard in this area. Along the extreme northern coast, concentrations of chloride exceed the $250-\mathrm{mg} / \mathrm{L}$ secondary drinking-water standard in both aquifers (Aucott and Speiran, 1986). Along the southern coast, the chloride standard is exceeded in the Black Creek aquifer. There, concentrations of chloride were about $900 \mathrm{mg} / \mathrm{L}$ in the Black Creek aquifer but generally range from 10 to $200 \mathrm{mg} / \mathrm{L}$ in the Middendorf aquifer. In much of the lower Coastal Plain, concentrations of dissolved sodium are several hundred milligrams per liter (fig. 4).

\section{Piedmont and Blue Ridge Aquifers}

Concentrations of alkalinity, hardness, sodium, magnesium, and chloride in water of the Piedmont and Blue Ridge aquifers are generally larger in geologic belts that were formed by low-grade metamorphism. However, other water-quality constituents do not appear to correlate with these belts (Patterson and Padgett, 1984). The quality of water from the Piedmont and Blue Ridge aquifers is generally within national drinking-water standards for most constituents. Concentrations of dissolved solids range from 22 to 1,100 $\mathrm{mg} / \mathrm{L}$ but exceed the $500-\mathrm{mg} / \mathrm{L}$ secondary drinking-water standard only in limited areas (Patterson and Padgett, 1984). The standard most often exceeded is the $50-\mu \mathrm{g} / \mathrm{L}$ limit for manganese, which is exceeded in almost all the Piedmont and Blue Ridge aquifers (Patterson and Padgett, 1984, p. 22). Hardness is another water-quality property affecting water use in large areas. Water is soft in most of the Piedmont and Blue Ridge aquifers but ranges from moderately hard to very hard in many areas. Drinking-water standards for several other water-quality constituents are exceeded in much more limited areas. These include $\mathrm{pH}$, chloride, fluoride, and nitrate.

\section{EFFECTS OF LAND USE ON WATER QUALITY}

Ground-water quality has deteriorated in some limited areas because of contamination from industrial, county and municipal, agricultural, and domestic sources. The South Carolina Department of Health and Environmental Control has documented humaninduced ground-water contamination from data derived by various permitting processes, from site investigations, and from compilation of a statewide inventory (Glowacz and others, 1980; McFadden, 1981; Hardee and McFadden, 1982; Ferguson and Workman, 1983). Many of the sites and wells that yield contaminated water are near Charleston, Columbia, Greenville, and Spartanburg. Problems with current or potential saltwater contamination have been identified in coastal areas.

\section{Industrial Sources}

Many instances of localized ground-water contamination from industrial sources have resulted from past waste-disposal practices that once were commonly accepted. Treatment, storage, and disposal of hazardous wastes occur at 33 RCRA facilities (fig. $3 A$ ). Groundwater contamination has been detected at 28 of these sites. Contaminants have not been detected or evaluation is incomplete at the five other sites. Ground-water contamination has been detected at 10 CERCLA sites, which are currently on the National Priorities List (NPL), and at 7 sites which are proposed additions (fig. $3 A$ ). Groundwater quality is threatened by soil contamination at two other sites. As of September 1985, 63 hazardous-waste sites at 8 facilities in South Carolina had been identified by the DOD as part of their Installation Restoration Program (IRP) as having potential for contamination (U.S. Department of Defense, 1986). The IRP, established in 1976, parallels the U.S. Environmental Protection Agency (EPA) Superfund program under CERCLA. The EPA presently , ranks these sites under a hazard ranking system and may include them in the NPL. Of the 63 sites in the program, 7 sites contain contaminants but do not present a hazard to the environment. Seven- 
teen sites at 4 facilities (fig. $3 A$ ) are considered to present a hazard significant enough to warrant response action in accordance with CERCLA. The remaining sites are scheduled for confirmation studies to determine if remedial action is required.

Contamination also has been identified at many other sites that may require remedial actions based on State regulations. Most of the contaminated sites in South Carolina are at chemical companies, manufacturing companies, gasoline stations, and U.S. Department of Energy facilities. The Savannah River Plant is a U.S. Department of Energy nuclear materials facility with about 164 waste-management sites. Hazardous waste at the plant is treated, stored, or disposed in trenches, in settling and seepage basins, and in underground storage tanks. Ground-water contamination has been detected at seven RCRA sites over a large area at the Savannah River Plant (fig. 3B. area A). Trichloroethylene, tetrachloroethylene, trichloroethane, other organic compounds, trace metals, and radionuclides (primarily tritium) have been detected in ground water at this facility.

In March 1986, trichlorethylene and other volatile organic compounds were detected in water of the Black Creek aquifer near an active hazardous-waste landfill in southern Sumter County. The source of contamination has been investigated by the site operator but the inquiry has not been completed.

Many small chemical companies and manufacturing facilities have caused localized ground-water contamination at sites that are neither RCRA nOr CERCLA sites (fig. 3A). Landfills, underground storage tanks, drums stored at land surface, unlined lagoons, and spray irrigation sites are common sources of ground-water contamination. Nitrate, sulfate, metals, and organic chemicals have been detected in ground water near these facilities.

Treatment and disposal of metals by spray irrigation and discharge into a seepage basin resulted in local ground-water contamination at a printing company in Lexington County. Concentrations of lead $(5,600 \mu \mathrm{g} / \mathrm{L})$, chromium $(620 \mu \mathrm{g} / \mathrm{L})$, and cadmium ( $780 \mu \mathrm{g} / \mathrm{L}$ ) were detected in shallow ground water. The company subsequently altered waste-handling practices, and no longer discharges waste into the ground water.

Spills and pipeline leaks also have contributed to groundwater contamination. In 1979 , about 800,000 gallons of fuel oil escaped from ruptures in a pipeline in Greenville County, resulting in localized contamination of the shallow saprolite part of the Piedmont and Blue Ridge aquifers. Although an attempt was made to clean the contamination, 162,000 gallons could not be recovered.

Leaking underground storage tanks at gasoline service stations also cause contamination of shallow ground water. Leaks usually are identified after hydrocarbons are detected in nearby domestic water wells or storm sewers. An extreme case occurred in Florence County where a contaminated site was investigated only after a city storm drain caught fire. Several sources of gasoline and fuel oil were discovered nearby, and recovery actions were implemented.

\section{County and Municipal Sources}

Ground-water contamination from county and municipal sources is usually associated with landfills (fig. $3 C$ ) or facilities for treating and disposing of waste water. Typical contaminants include metals, nutrients, insecticides, herbicides, waste oils, and other organic compounds. Typically, contamination at landfills is localized and affects shallow ground water underneath a limited area. However, landfills located in recharge areas for deeper aquifer systems are a greater threat to ground-water quality. One such landfill in a coastal county is located in a recharge area for the Floridan aquifer system. The contaminant plume, which contains nutrients and organic compounds, is at least 33 feet deep, with the top of the Floridan aquifer system about 100 feet deep.
Waste water from an unlined municipal sewage lagoon in Lexington County contaminated shallow ground water with chromium $(1,100 \mu \mathrm{g} / \mathrm{L})$, lead $(1,380 \mu \mathrm{g} / \mathrm{L})$, iron $(200,000 \mu \mathrm{g} / \mathrm{L})$, and nickel $(400 \mu \mathrm{g} / \mathrm{L})$. The contaminant plume is 10 feet deep but appears to discharge into a nearby stream. No public water-supply wells have been closed as a result of contamination from municipal and county sources.

\section{Agricultural Sources}

The use of fertilizer, insecticides, and herbicides in irrigated agricultural fields has caused local contamination of shallow ground water with nitrate, phosphate, and organic chemicals (DDT, DBCP, and endosulfan). The accumulation of large quantities of nitrogenrich animal wastes has caused nitrate contamination of ground water near two feedlots. Six private and five public water-supply wells have been affected.

Contamination of the water-table aquifer in an area of about $5 \mathrm{mi}^{2}$ (square miles) north of the city of Sumter has been attributed to agricultural sources. Concentrations of nitrate as nitrogen ranged from 33 to $250 \mathrm{mg} / \mathrm{L}$ in the area. Another site with similar contamination was identified where monitoring wells were installed in a proposed subdivision that was to be supplied by shallow water wells. Concentrations of nitrate of as much as $12 \mathrm{mg} / \mathrm{L}$ were traced to a combination of fertilizer application, septic tanks, and animal feedlots.

\section{Domestic Sources}

Contamination resulting from domestic sources is associated most commonly with septic tank drain fields, improper storage of chemicals, spills, and fuel oil leaking from tanks. Bacterial contamination of shallow ground water at a subdivision in Lexington County was caused by a dense accumulation of septic-tank systems and resulted in the temporary closure of one public water-supply well.

Improper storage of organic chemicals contaminated ground water near a domestic well in Horry County. Alachlor $(1,730 \mu \mathrm{g} / \mathrm{L})$, carbofuran $(4,000 \mu \mathrm{g} / \mathrm{L})$, and carbaryl $(360 \mu \mathrm{g} / \mathrm{L})$ were detected in the domestic well water. Spills related to termite treatment at a residence in York County contaminated a private well with chlordane $(0.42 \mu \mathrm{g} / \mathrm{L})$. Fuel oil from above-ground and underground storage tanks has contaminated domestic wells in Laurens and Lexington Counties. An abandoned domestic well, which had been completed in the Floridan aquifer system in Beaufort County, was mistaken for an access port to a fuel-oil tank, and a large amount of fuel oil was pumped into the well. Five hundred gallons of fuel oil were recovered.

\section{Saltwater Contamination}

Saltwater contamination has occurred along the coast of South Carolina through two processes: excessive ground-water withdrawals and hydraulic connection of freshwater and saltwater aquifers. Ground-water withdrawals, particularly near Savannah, Georgia, and Hilton Head Island, South Carolina, have resulted in water-level declines and reversal in the water-level gradient that have increased the potential for saltwater intrusion into the Floridan aquifer system. The potential for intrusion is increasing because ground-water withdrawals are increasing as the population of the area increases. There is also a potential for saltwater intrusion into the Black Creek aquifer in the Myrtle Beach area where water levels have declined more than 100 feet since major pumping began and are continuing to decline as much as 9.5 feet per year. Saltwater contamination also has occurred in open-hole wells that hydraulically connect freshwater and saltwater aquifers in coastal areas of South Carolina. 


\section{POTENTIAL FOR WATER-QUALITY CHANGES}

The greatest potential for change is in ground-water quality near aquifer recharge areas, particularly near aquifer outcrops. These areas are most subject to change because downward potentiometric gradients will allow contaminants to move into deeper aquifers. One area of major concern is along the Fall Line where the Tertiary sand and Middendorf aquifers crop out (fig. 2A1). Because of the significant permeability and small clay content of most sediments, recharge rates are rapid and retardation of contaminant movement is usually negligible. The limited buffering capacity of the ground water in this area makes the water quality susceptible to changes in $\mathrm{pH}$ caused by introduction of chemicals from outside sources. A major part of the Columbia metropolitan area (fig. $1 A$ ) is located on the Tertiary sand and Middendorf aquifer outcrop. The numerous contamination sites in the area (fig. 3A) further indicate the concern for future contamination of deeper parts of the aquifers.

Ground-water contamination in areas near the Fall Line also may have a significant effect on surface-water quality where streams deeply incise the land surface. The deep incisement combined with significant rates of ground-water recharge result in rapid rates of ground-water discharge to the streams, producing some of the highest base flows in streams in the State. Thus, contaminated ground water may ultimately contaminate rivers and streams.

The potential for water-quality changes is increasing near expanding industrial and urban centers. Specifically, the growth of industry along the corridors of interstate highways near Columbia, Greenville, and Spartanburg (fig. $1 A$ ) has the potential to change the quality of the ground water in these areas. General land use in urban areas also may change ground-water quality by affecting the quality of recharge water. Development of coastal areas and the accompanying increase in ground-water withdrawals will increase the potential for saltwater intrusion.

Trends in agricultural and residential practices also increase the potential for changes in ground-water quality. Application of fertilizers, herbicides, and insecticides is increasing. Such application is often made by irrigation systems, which are being used more extensively. If chemicals are applied improperly to croplands and residential areas or are handled carelessly, severe ground-water contamination can occur over extensive areas.

Contaminants that have been identified at several sites across the State in the shallow parts of the aquifer are being removed by treatment. These operations will decrease contamination and are intended to prevent contamination from migrating into deeper aquifers.

\section{GROUND-WATER-QUALITY MANAGEMENT}

The South Carolina Department of Health and Environmental Control (DHEC) has the primary responsibility for managing groundwater quality throughout South Carolina. The South Carolina Water Resoures Commission (WRC) has limited responsibility for managing ground-water quality in designated-capacity use areas.

Federal ground-water-quality legislation has been implemented by the DHEC through various State and Federal funding programs. Program management and work-plan objectives are in accordance with the Safe Drinking Water Act of 1974 and its amendments. The State Primary Drinking Water Regulations were adopted in 1981 by the DHEC and have been implemented.

The State's ground-water-protection policy provides for nondegradation of ground-water resources. All aquifers in the State have been classified GB (underground sources of drinking water) by regulations under the State's Water Classifications and Standards of 1985. Ground water that is extremely vulnerable to contamination may be classified as GA if it meets certain criteria. This classification provides for greater protection of the ground water.
Ground water also may be classified GC if it cannot be used for public supply because of its quality. Currently (1986), no ground water is classified as GA or GC.

CERCLA and RCRA programs are administered by the Bureau of Solid and Hazardous Wastes Management with technical assistance on ground-water issues provided by the Bureau of Water Supply and Special Programs (BWSSP). Many spills of hazardous substances have been reported as a result of the CERCLA comprehensive notification program. Hazardous materials in the RCRA program are handled persuant to the State's Hazardous Waste Management Act of 1978 and the Hazardous Waste Management Regulations. Evaluation of 33 RCRA sites is in progress.

The State's discharge-permitting process facilitates the identification of existing contamination and decreases the potential for future contamination. Within the BWSSP, the Ground Water Protection Division manages and implements programs for Underground Injection Control and for Underground Storage Tanks, adopted in 1983 and 1985, respectively. Well drillers are required to be certified, and wells must be constructed according to South Carolina Well Standards and Regulations. A network for sampling the background quality of ground water is being developed, and a public education program has been implemented through the Speakers Bureau of the Department of Health and Environmental Control.

Under the Ground-Water Use Act of 1969, the WRC has the authority to regulate ground-water withdrawals within designated capacity-use areas. The purpose of this Act is to minimize the adverse effects of excessive pumping on the availability and quality of ground water where the resource is threatened. All users withdrawing $100,000 \mathrm{gal} / \mathrm{d}$ (gallons per day) or more within these areas must obtain a permit from WRC and report monthly usage quarterly.

State ground-water protection programs have been supported by regional, multicounty, and local geohydrologic and water-quality investigations. Background data on ground-water quality have been collected by the WRC, the DHEC, and the U.S. Geological Survey. Geohydrologic knowledge of the Piedmont and Blue Ridge provinces generally is not as complete as for the Coastal Plain province.

\section{SELECTED REFERENCES}

Aucott, W.R., and Speiran, G.K., 1986, Geohydrology and water quality of the Coastal Plain aquifers of South Carolina, in McGill, H.J. and Stone P.A., (eds.), 1986, Proceedings-Symposium on ground water and environmental hydrogeology in South Carolina: Columbia, South Carolina Department of Health and Environmental Control, Ground Water Protection Division, p. 26-50.

Fenneman, N.M., 1938, Physiography of Eastern United States: New York, McGraw-Hill Book Co., 714 p.

Ferguson, J.M., and Workman, S.M., 1983, A report to the General Assembly on ground-water contamination in South Carolina: Columbia, South Carolina Department of Health and Environmental Control, Ground Water Protection Divison, 103 p.

Glowacz, M.E., Livingston, C.M., Gorman, C.L. and Clymer, C.R., 1980, Economic and environmental impact of land disposal of wastes in the shallow aquifers of the lower coastal plain of South Carolina: Columbia, South Carolina Department of Health and Environmental Control, Ground Water Protection Division, $100 \mathrm{p}$.

Hardee, H.K., and McFadden, S.K., 1982, Inventory of known ground water contamination cases and generalized delineation of five groundwater recharge areas in South Carolina: Columbia, South Carolina Department of Health and Environmental Control, Ground Water Protection Division, $120 \mathrm{p}$.

Lonon, G.E., Burnette, C.B., and Morris, H.J., 1983, Water use in South Carolina, 1980: Columbia, South Carolina Water Resources Commission Report No. 138, 20 p.

McFadden, S.K., 1981, Ground-water investigation at Booth Farms and Laney's Mobile Home Park, Sumter County, South Carolina: 
Columbia, South Carolina Department of Health and Environmental Control, Ground Water Protection Division, 44 p.

Oldham, R.W., Stone, P.A., and Clark, S.L., 1986, Short-circuiting in saprolite by recharge waters in Piedmont aquifers of South Carolina: Geological Society of America Abstracts, with Programs, v. 18, no. 6, p. 710 .

Patterson, G.G., and Padgett, G.G., 1984, Quality of water from bedrock aquifers in the South Carolina Piedmont: U.S. Geological Survey Water-Resources Investigations Report 84-4028, 24 p.

Raisz, Erwin, 1954, Physiographic diagram, p. 59, in U.S. Geological Survey, 1970, National atlas of the United States: Washington, D.C., U.S. Geological Survey, 417 p.

U.S. Bureau of the Census, 1982, Census of the population, characteristics of the population, number of inhabitants-1980: U.S. Bureau of the Census, Published separately by States, Puerto Rico, and outlying areas, $\mathrm{PC} 80-1-\mathrm{Al}$ to $\mathrm{A} 57 \mathrm{a}$, and $\mathrm{A} 57 \mathrm{~b}$.

U.S. Department of Defense, 1986, Status of the Department of Defense Installation Restoration Program-Information paper: Washington, D.C., U.S. Department of Defense, Office of the Assistant Secretary of Defense (Aquisition and Logistics), Environmental Policy Directorate, February, $35 \mathrm{p}$.
U.S. Environmental Protection Agency, 1986a, Maximum contaminant levels (subpart B of part 141, National interim primary drinking-water regulations): U.S. Code of Federal Regulations, Title 40, Parts 100 to 149 , revised as of July 1, 1986, p. 524-528.

$1986 \mathrm{~b}$, Secondary maximum contaminant levels (section 143.3 of part 143, National secondary drinking-water regulations): U.S. Code of Federal Regulations, Title 40, Parts 100 to 149, revised July 1, 1986, p. $587-590$.

1986c, Amendment to National Oil and Hazardous Substances Contingency Plan; national priorities list, final rule and proposed rule: Federal Register, v. 51, no. 111, June 10, 1986, p. 21053-21112.

U.S. Geological Survey, 1985, National water summary, 1984-Hydrologic events, selected water-quality trends, and ground-water resources: U.S. Geological Survey Water-Supply Paper 2275, 467 p.

Zack, A.L., 1980, Geochemistry of fluoride in the Black Creek aquifer system of Horry and Georgetown Counties, South Carolina-and its physiological implications: U.S. Geological Survey Water-Supply Paper 2067, 40 p.

Prepared by Gary K. Speiran, U.S. Geological Survey, and Richard W. Oldham, Donald A. Duncan, and Raymond L. Knox, South Carolina Department of Health and Environmental Control, Ground Water Protection Division.

FOR ADDITIONAL INFORMATION: District Chief, U.S. Geological Survey, 1835 Assembly Street, Suite 658, Columbia, SC 29201 


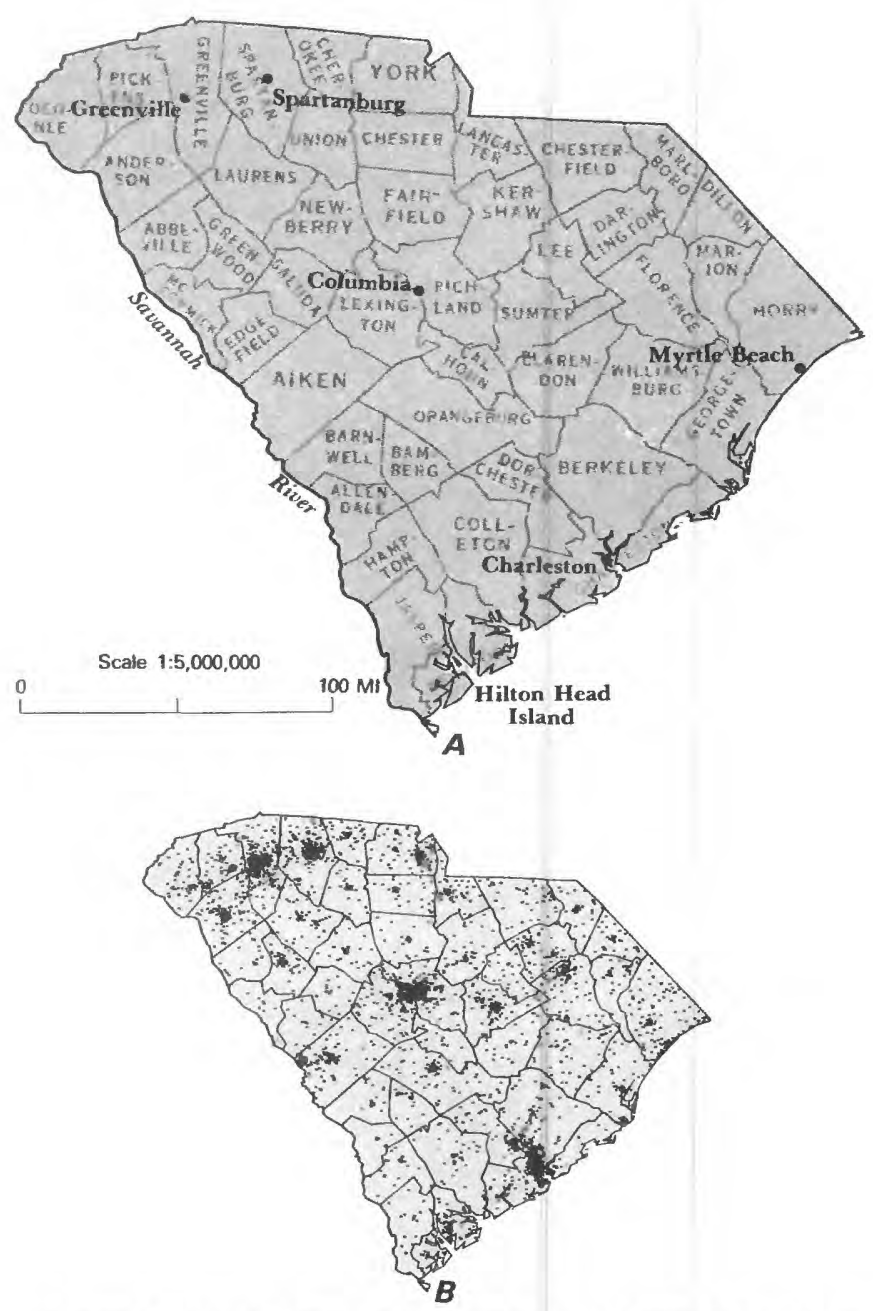

Figure 1. Selected geographic features and 1985 population distribution in South Carolina. A, Counties, selected cities, and major drainages. $B$, Population distribution, 1985; each dot on the map represents 1.000 people. (Source: B. Data from U.S. Bureau of the Census 1980 decennial census files, adjusted to the 1985 U.S. Bureau of the Census data for county populations.) 

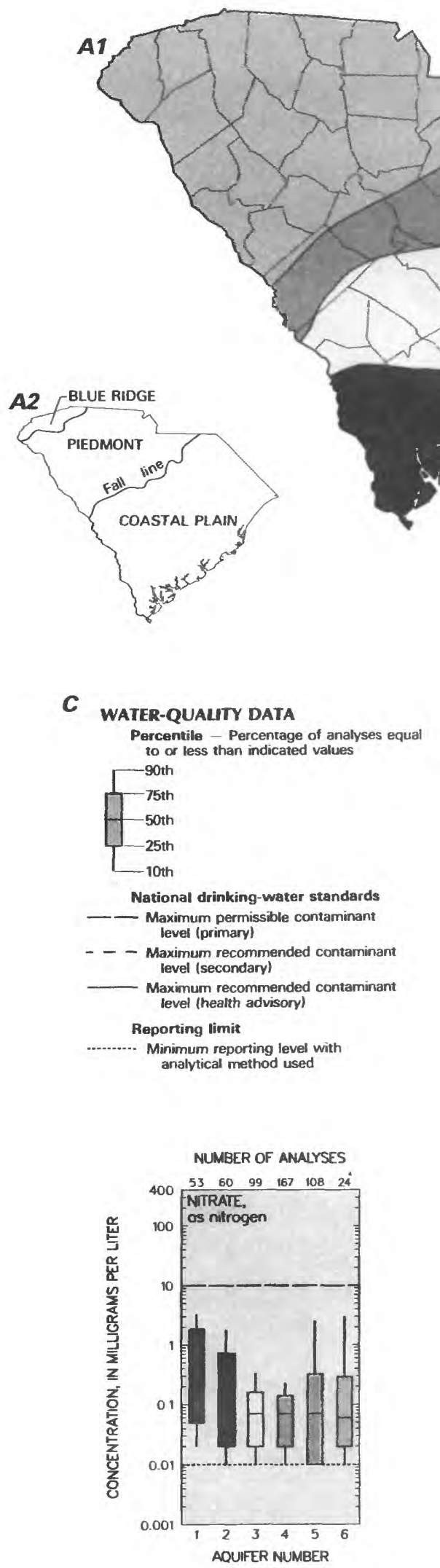

NUMBER OF ANALYSES

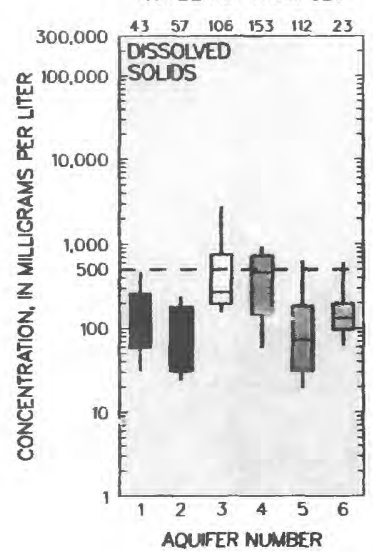

NUMBER OF ANALYSES

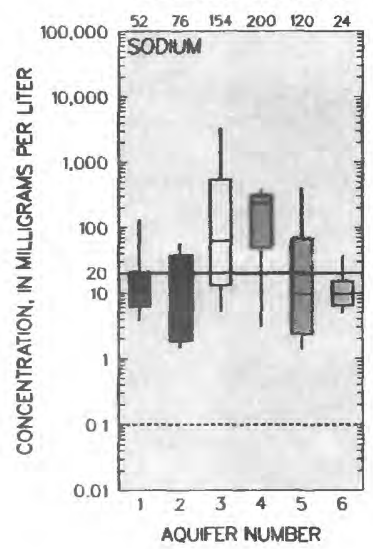

PRINCIPAL AQUIFER - Numeral is aquifer number in figure $2 \mathrm{C}$

Shallow aquifers (1)

Floridan aquifer system (2)

Tertiary sand (3)

Black Creek (4)

Middendorf (5)

Piedmont and Blue Ridge aquifers (6)

Confining unit

NORTHWEST

SOUTHEAST
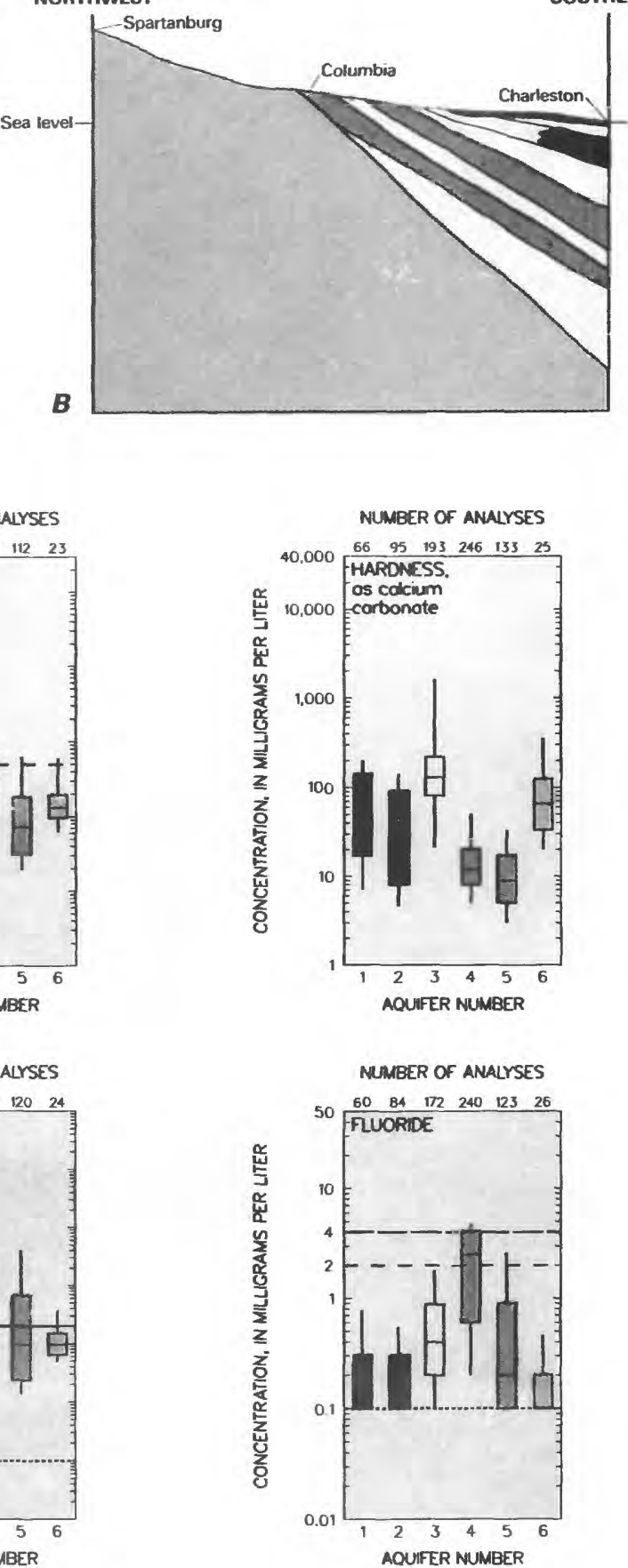

Figure 2. Principal aquifers and related water-quality data in South Carolina. $A 1$, Principal aquifers; $A 2$, Physiographic provinces. $B$, Generalized hydrogeologic section. C. Selected water-quality constituents and properties, as of 1946-85, (Sources: A1, A2, B. U.S. Geological Survey, 1985. C, Analyses compiled from U.S. Geological Survey files; national drinking-water standards from U.S. Environmental Protection Agency, 1986b,c.) 


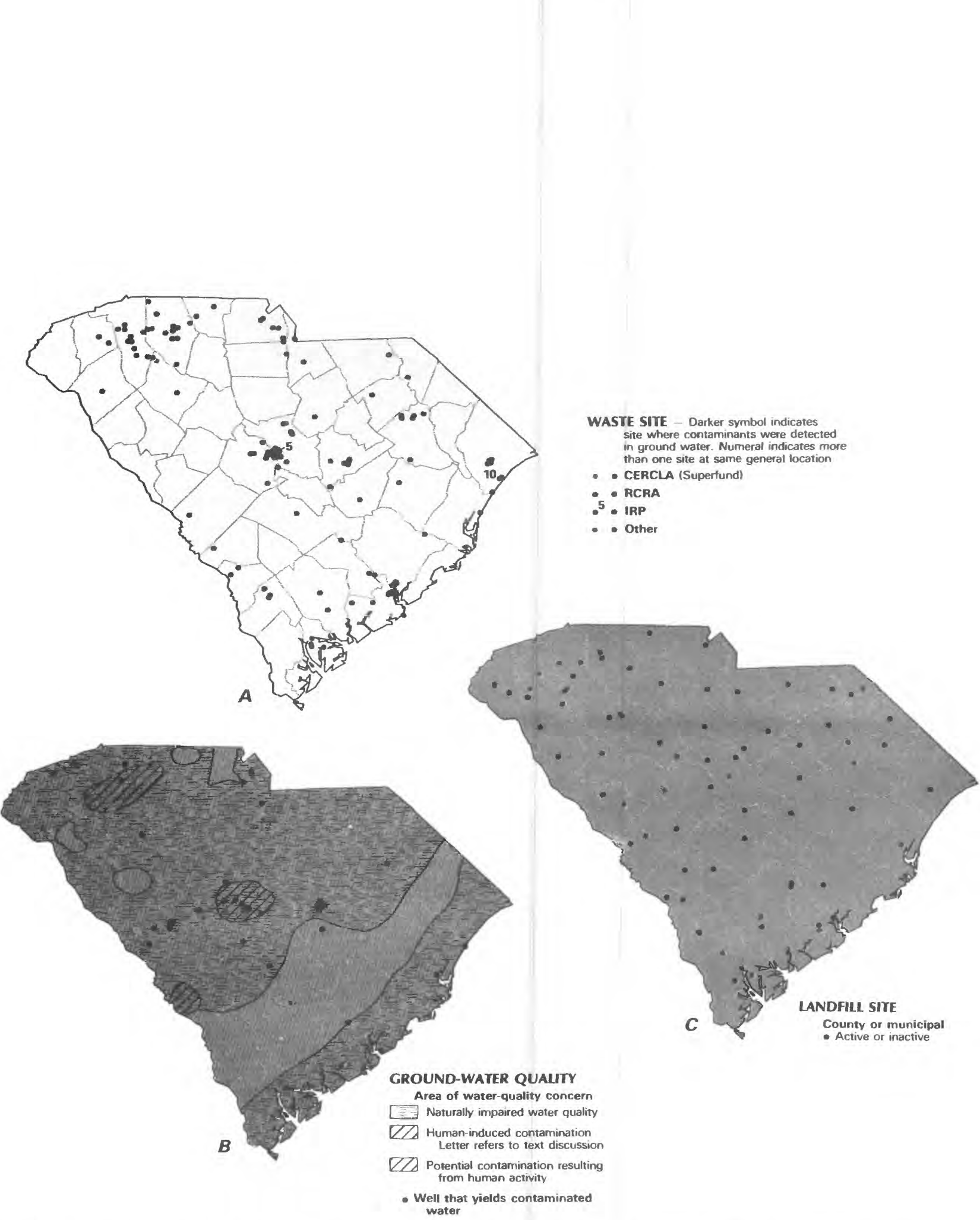

Figure 3. Selected waste sites and ground-water-quality information in South Carolina. A, Comprehensive Environmental Response, Compensation, and Liability Act (CERCLA) sites, as of June 1986; Resource Conservation and Recovery Act (RCRA) sites, as of June 1986; Department of Defense Installation Restoration Program (IRP) sites, as of September 1985; and other selected waste sites, as of June 1986. B. Areas of naturally impaired water quality, areas of human-induced contamination, and distribution of wells that yield contaminated water, as of June 1986. C. County and municipal landfills, as of June 1986. (Sources: A, South Carolina Department of Health and Environmental Control files. B. Human-induced contamination and wells from South Carolina Department of Health and Environmental Control files; Naturally impaired water quality from U.S. Geological Survey files, and Patterson and Padgett, 1984. C. South Carolina Department of Health and Environmental Control files.l 

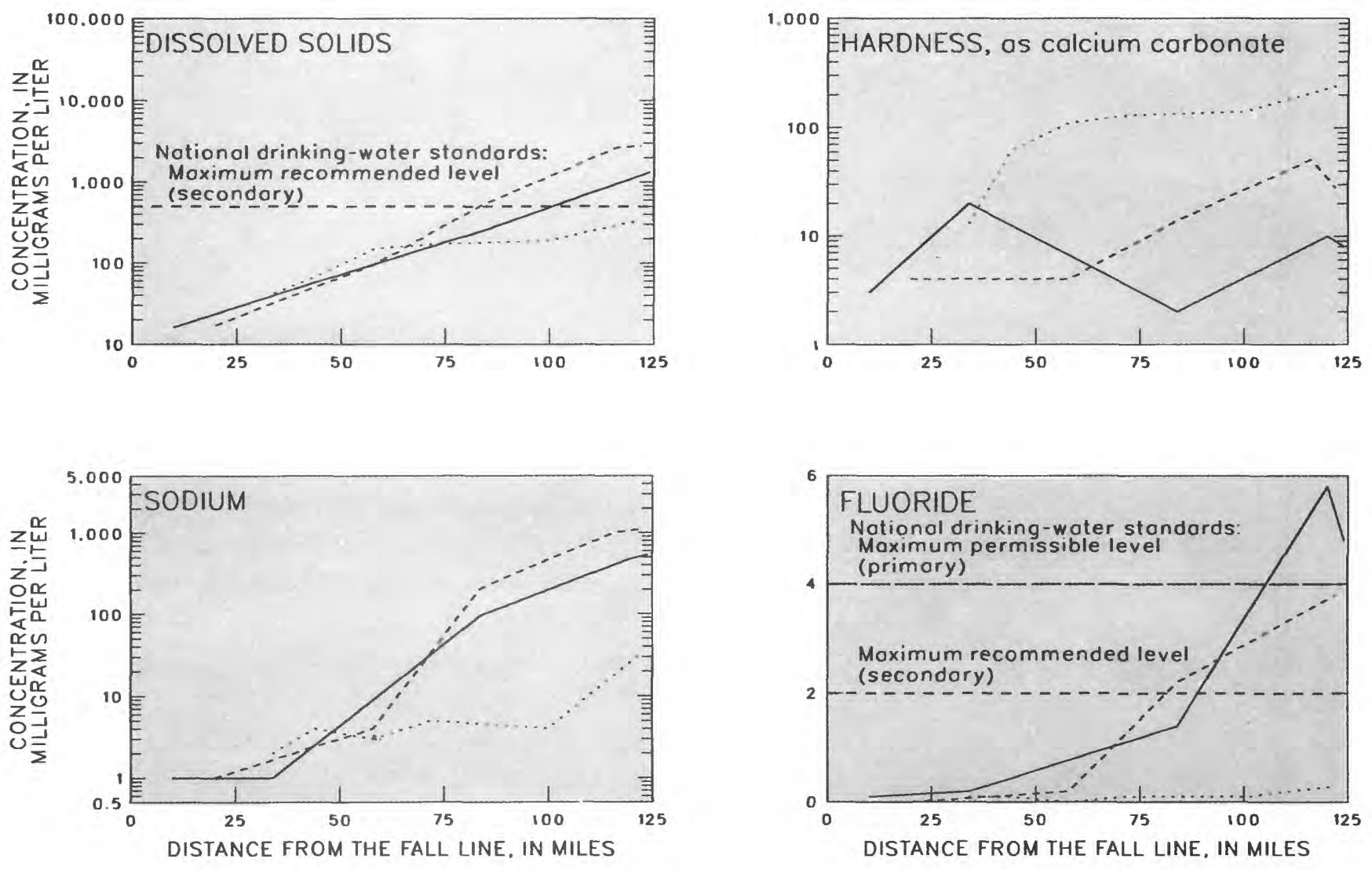

EXPLANATION

…... Floridan aquifer system and Tertiary sand aquifer

- . - - Black Creek aquifer

Middendorf aquifer

Figure 4. Water quality along flow paths from the recharge area toward the coast in the Floridan aquifer system and the Tertiary sand aquifer the Black Creek aquifer, and the Middendarf aquifer in South Carolina. (Source: U.S. Geological Survey files.) 